Some may have seen James Souness as a demanding man, but he asked no more of others than he was prepared to give himself. He was a friendly person and his ready sense of humour was never far away, as many who heard his after-dinner speaking can confirm. He was a committed Christian, an elder and member of the choir in his Church, which he served in many ways. He maintained a lifelong connection with the Boys' Brigade and showed his concern for young people in his work as Finance Convener of the Royal Scottish Society for the Prevention of Cruelty to Children. He had a great zest for life, entering with enthusiasm and vigour into every activity; indeed activity, whether mental or physical, was a compulsion with him.

Jim had a natural talent for ball games. As a boy, it is said, he played rugby in the morning, football in the afternoon and table-tennis at night. His ability at soccer was noticed by Hibernian and he joined that famous Edinburgh club as a part-time professional. Perhaps the highlight of his footballing career came when he was a member of the Heart of Midlothian team which won the Scottish League Cup in 1955. At cricket he was capped three times for Scotland.

When his cricketing and footballing days came to an end, he maintained his obsession with fitness by taking up golf, where he quickly brought his handicap down to single figures, and by continuing to play the occasional game of tennis. Shortly afterwards he became interested in hill-walking and in 1984 he joined that small band of a few hundred people who have completed the ascent of all 277 Munros (Scottish mountains of over 3,000 feet). He enjoyed the exhilaration and freedom of the tops and was a good companion on the hills. Ever seeking greater challenges, he took up rockclimbing in Glencoe and on Ben Nevis and went on to climb Mont Blanc, the highest mountain in Europe. To mark his retirement from the Life Association he arranged to take his two sons on a climbing trip to Switzerland and it was there, just after reaching the summit of the Mönch, that he slipped and fell to his death.

Although modest about his artistic abilities, Jim Souness had an extensive memory of the works of the English poets and a great love of music. On his homeward drive after a day's climbing he liked nothing better than to listen to a Mozart piano concerto; he was Chairman of the Music Committee of the Scottish Arts Councils at the time of his death.

Above all, Jim Souness was a family man and he and his wife Ena got much joy from the achievements of their children and grandchildren.

W. M. M.

\title{
John Leslie Anderson MA, FIA, FFA
}

Leslie Anderson was a very talented man. He had a first class mathematical brain, an orderly mind, a very high work rate, an ability to make understandable the most confusing of problems and finally he had commonsense.

Born on 12 July 1904 at West Hartlepool of Scottish parents he was educated at Mill 
Hill School, London. He gained an open scholarship to St John's College, Oxford and graduated in mathematics with first-class honours in 1926. He enrolled as a student with the Institute of Actuaries in October that year and qualified as a Fellow in 1930.

In 1926 he had applied to the Scottish Widows' Fund and Life Assurance Society (hereafter simply called the Widows) London Branch for a position on their staff but had to sit a test in mathematics. He must have passed as he was then offered a post as a junior clerk. He served in this capacity for 18 months and was then transferred to the Head Office in Edinburgh he soon made many friends and was made welcome.

Some time after he qualified as a Fellow of the Institute he was invited by the Faculty to serve as a tutor and served in this capacity for some years. Later he also served as a Faculty representative on the Actuarial Tuition Service and the Continuous Mortality Investigation Bureau. The Faculty rewarded him by electing him a Fellow in 1953a rare honour. He was elected to the Council and served on it and numerous committees. In 1964 he was elected President.

While all this was taking place his carcer at the Widows was progressing satisfactorily. In 1932 he received his first official position-Joint Assistant Actuary. After holding many other positions he became Secretary in 1947-Secretary was then the title of the second official who normally was the heir apparent.

He became General Manager and Actuary in 1961 and retired in 1969 a very successful 8 years in which the Widows continued to produce excellent results. However the greatest service he did his Company was his advocacy in 1944 and onwards of a high proportion of the funds, being invested in ordinary shares. Even those not skilled in investment matters can see that difficult problems about matching, the effect on the Stock Market, and even on British Industry would arise at that timeat the back of his mind must have been the terrible depression that followed the first world war.

Leslie however must have answered these and all other questions to the satisfaction of his General Manager and Board and he got the go ahead.

By this action he contributed greatly towards the reputation the Widows has for excellent results.

Leslie retained his interest in investments after he became Secretary of the Widows and showed excellent judgement in the selection of shares. This brought him to the notice of the financial circles in Edinburgh and he was invited to become Director of the Edinburgh Investment Trust. He also served for many years on the General Finance Committee of the Church of Scotland (he was later Governor) and of the University of Edinburgh Trust (later Chairman).

As well as his more high profile positions he also acted as Treasurer of a small fund which gave small sums of money to deserving old people who found difficulty in feeding and keeping themselves warm on their state pension. He gave the same meticulous attention to his duties here as he did to his duties in more famous organisations. 
He still however found time for leisure. One of his greatest joys was striding over the mountains of Scotland and the Lake District. He estimated that on these strolls he 'bagged' over 170 Munros (mountains of 3,000 feet or over).

His other main interest was the theatre and amateur dramatics. He visited the theatre whenever possible and would have made an excellent drama critic for the Scotsman newspaper. He was a veritable tower of strength in amateur drama in Edinburgh. He wrote plays, he produced plays and he acted - all to a high standard. As if this was not enough he also served on the Council of the Edinburgh International Festival.

What of the man himself? Well he was a quict man who never sought the headlines but at the same time he was a good companion. He was what I would call a 'practical' Christian. How many of us I wonder would visit a decent old man living alone in a 'single end' in a dilapidated tenement, well this former President and former General Manager of the Widows, for many years visited three such men once a month bringing with him the money from the charity. As Leslie had no small talk he took his wife Ida with him so that there would be no embarrassing silences, somebody cared.

He was a good man. 